\title{
2
}

\section{THE ORIGINAL NORTH AMERICAN PETROLEUMSCAPE}

\section{Oil-and-Gas Empire, Petrochemical Nation}

\section{Carola Hein and Alan Lessoff}

The first-and perhaps most all-encompassing-petroleum-created landscape emerged in the US. With its massive refinery and petrochemical complexes; its pipelines crisscrossing the continent; its petroleum-oriented ship channels, offshore rigs, and tanker-loading platforms; with its land use configurations, employment patterns, institutions, political economy, and material culture all tracing their character to oil as a business and as a way of life, the US serves as a case in point for the analysis featured in this book. ${ }^{1}$

By the late 1850s — when petroleum's commercial potential became evident — coal mining and steam technology had already incorporated fossil fuels into transportation, industry, and everyday life. By the mid-century, Philadelphia, Pittsburgh, Chicago, and other eastern and midwestern industrial cities were becoming hubs of coal-railroad-metalmaking complexes comparable to the German Ruhr region or the English Midlands. Even in coal-oriented US cities, considerable flux characterized business relations, labor and class structure, and urban geography throughout the late 1800s. With only loose path dependence on coal, these cities were open to the novel forms of capital investment and energy use that oil and gas represented. In addition, in entire US regions, especially the Southwest and West, urban and commercial networks and energy-use patterns were still in formative stages when the shift of energy regimes from coal to petroleum began to reshape cities and urban culture. The US was thus highly receptive to its landscape becoming the kernel of the global petroleumscape. ${ }^{2}$

Between the 1850s and 1950s, the US became oriented around the production, marketing, and consumption of petroleum. Freeways carved up cities, which stretched outward into a succession of freeways, subdivisions, shopping centers, and office parks, the stereotyped manifestations of North America's petroleumscape. This diffuse, segmented, multicentered urban form appeared with particular clarity in the US Southwest, whose urbanization, largely catalyzed by enormous oil and gas discoveries in the early twentieth century, took shape in tandem with the ubiquitous adoption of the automobile, without a firm legacy from the walking city and railroad eras. The petroleumscape came to pervade rural areas and small towns as well. Farms became part of the petroleumscape, dependent on gasoline and diesel machinery and chemical fertilizers and pesticides. The extraction, 
refining, transportation, and consumption of petroleum reshaped rivers, coasts, and seas. The spatial patterns and material culture associated with oil and gas became fundamental to Americans' imagination of themselves as a nation.

While the North American petroleumscape has distinctive aspects, its influence pervades the petroleumscape around the world. Driven by entrepreneurial and corporate capital rather than state enterprise, the US gave birth to vertically and horizontally integrated petroleum companies that came to control the industry in large parts of the world. At a time when European nations were still expanding (or even building) their colonial realmsoften with an eye on access to oil-entrepreneurs from the US were constructing a neocolonial system of multinational energy firms, whose networks of extraction, processing, and marketing spanned the globe. This petroleumscape grew to include built infrastructures and urban forms in select locations outside the US, but only to the extent that these served the main purpose of the company: the extraction, refining, and selling of petroleum.

This chapter explores the early North American petroleumscape, from the 1850s into the years after World War II, with an emphasis on the many ways the petroleum industry reshaped cities, urban networks, and relations between regions within the US and across the North American continent. As the chapter moves into the twentieth century, it expands geographically from petroleum's initial base in Pennsylvania and Ohio to what historian Carl Abbott has termed the "Energy West." 3 The petroleum-driven transformation of the territory from Houston to Los Angeles began with spectacular oil booms in Southern California and East Texas in the 1890s and early 1900s. This transformation ended with Houston as the energy industry's global headquarters, and with immense swaths of the continent-from Louisiana and the Gulf of Mexico through Oklahoma and Colorado and onward into Alberta and Alaskaan interconnected system of exploration, drilling, refineries, pipelines, and petrochemicals.

\section{The North American Petroleumscape in the Kerosene Era}

The North American oil story began in Western Pennsylvania, near Titusville north of Pittsburgh. There, Edwin Drake (1819-1880) drilled for oil in 1859, setting off the first oil rush. Once oil had been found, the main challenge involved transporting it to refining sites, with horse carts, ships, and pipelines all playing a role. By the early 1860s, railroads reached into the oil fields, allowing the slippery substance to be transported to Cleveland or Pittsburgh to be refined. As consumers adopted new uses of petroleum-in particular, it quickly replaced whale oil for lighting-businesses rapidly expanded storage, refining, and shipping capacities. Production increased from some 4,450 barrels in the first year to 220,000 barrels in 1860 and 2,114,000 barrels in 1861 .

The Western Pennsylvania boom thus compelled the rushed creation of the first layer of the spatial petroleumscape, oil's industrial footprint: petroleum's extraction, storage, transformation, and transportation. During these early years, a large number of interests battled for control, among them John D. Rockefeller, a Cleveland merchant who invested heavily in kerosene and naptha refining during the US Civil War. Combining technological innovation with aggressive business methods, Rockefeller and his partners made Cleveland the hub of the early oil industry. By the mid-1870s, their firm, Standard Oil, had acquired a network of refining operations in Atlantic coastal ports. By the 1880s, as Daniel Yergin points out, Standard Oil refineries in Cleveland, Philadelphia, and Bayonne, New Jersey, together produced over a quarter of the world's kerosene. Standard's enormous Bayonne refinery along New York Harbor was a major reason that the New York area came to account 
for over 40 percent of Standard Oil's production and nearly three-quarters of its exports. Oil refining also had a presence in the East Coast ports of Baltimore, Boston, and Portland, Maine, but their role was negligible next to New York/New Jersey and Philadelphia. ${ }^{4}$

Philadelphia's durable role in both domestic and trans-Atlantic markets was built on the city's history as a port, its status as terminus and headquarters of the Pennsylvania Railroad, and its strategic links to Western Pennsylvania. With extensive unbuilt land on the Schuylkill and Delaware Rivers, the city offered ample rail and water infrastructure as well as access to water for the new industry. Philadelphia also offered a diverse, highly skilled industrial base that produced everything from locomotives and tools to textiles and beer. The boom-and-bust pattern of refineries in Philadelphia and their changing locations illustrate the ways in which the emerging industry explored locational preferences, inserted refineries into cities with favorable, pre-existing industrial bases and transportation networks, but then reshaped the infrastructure of those cities and redirected their development. The pattern underscores the power of consolidation in strategically located cities with strong infrastructural connections through rail, road, shipping, and pipelines. ${ }^{5}$

The location of oil facilities in the Philadelphia region depended on a range of factors, especially access to water, both for industrial processes and for shipping. By 1866, the city listed seven petroleum storage facilities and six refineries. Several more appeared by 1875 . Disasters made safety a concern. Environmental considerations became an additional reason to relocate. The Belmont Petroleum Refinery was initially located between the Philadelphia and Reading Railroad and the Schuylkill River, just above the Columbia Bridge where the Pennsylvania Railroad split from the Junction Railroad. This facility produced some two million gallons of petroleum products in 1868, but because it was located upstream from the municipal waterworks, its wastewater endangered the city's drinking water supply. Along with other industrial properties in the vicinity, the Belmont Refinery ultimately closed, and the city bought the land as an extension of Fairmount Park. After the Belmont refinery stopped operations, two new petroleum centers emerged: one would disappear, while the other has lasted until the present era. Both were built on agricultural land within city limits, downstream from the drinking water intake, where it was easier for companies to create industrial complexes and to run new railroads (Figure 2.1).

The Atlantic Refining Company, founded by Pittsburgh and Philadelphia investors, occupied a seventy-acre property on the Schuylkill just below the Point Breeze Gas Works. Like other Philadelphia industrial businesses at the time, the Atlantic refinery preferred to portray itself as modern but also scenic and in harmony with nature, not as a disruptive social and environmental force of Charles Dickens-style foreboding (Figure 2.2). In 1874, Standard Oil purchased the Atlantic Refining Company as part of its attempt to consolidate oil transport and refining into a single enterprise capable of weathering major setbacks, even the destruction of an entire facility. This happened in 1879, when lightning destroyed the Atlantic refinery along with several ships moored on its wharves. Two thousand men lost their jobs, and many of the seamen from the ship lost all their belongings. Standard Oil carried no insurance and had to pay for reconstruction. Yet the company was already big enough to absorb such a loss. ${ }^{6}$

The Pennsylvania Railroad, meanwhile, purchased a large plot of land on the Delaware at Greenwich Point, about 1.75 miles south of the Navy Yard, for leasing to independent oil operators. For a time, these independents and the Pennsylvania Railroad engaged in a shipping rate war against the combined power of Standard Oil, the Baltimore \& Ohio Railroad, New York Central Railroad, and Erie Railroad. Ultimately, the Pennsylvania Railroad lost 


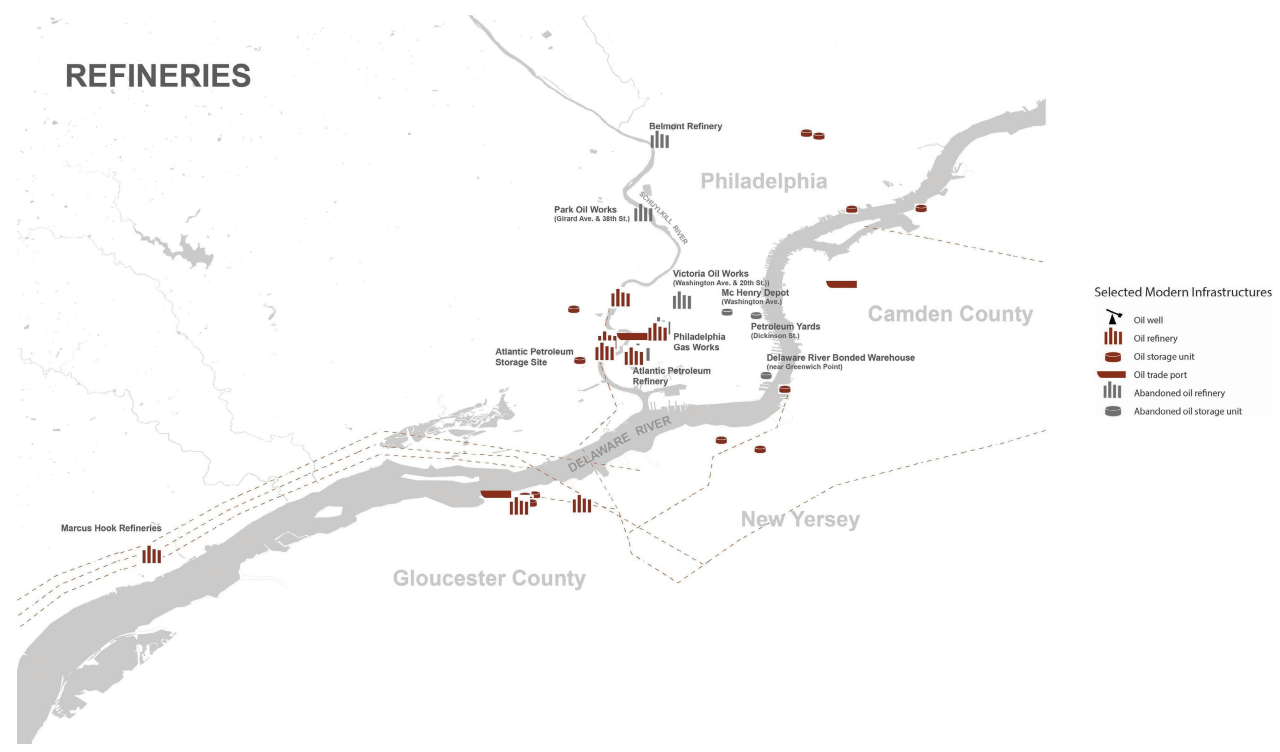

FIGURE 2.1 Locations of historical and modern refineries in Philadelphia and Marcus Hook. Map by Carola Hein and Arnoud de Waijer.

the contest and sold its oil interests to Standard Oil. ${ }^{7}$ The Delaware facilities continued to work until 1911, and then disappeared.

The rebuilt Atlantic refinery at Point Breeze benefited from Standard's consolidation and expansion, so much so that for a time, the company's Philadelphia operations produced on a scale comparable to those in New York. By 1891, 35 percent of all US petroleum exports came from the 360-acre Point Breeze plant, which featured a navigable waterfront of 1.7 and 6 miles of private railroad track. The facility burned 350,000 tons of coal each year to refine 40,000 barrels of petroleum daily, which underscores the connection between Philadelphia as a center of coal transport and as a petroleum hub. Continued tensions between Standard Oil and the Pennsylvania Railroad prompted Rockefeller to divert trade back toward New York, which in any case had succeeded Cleveland as the company's headquarters after the formation of the Standard Oil Trust in $1882 .^{8}$

Still, as of 1907, petroleum products exported by the Atlantic Refining Company (owned by Standard Oil) accounted for 22 percent of the city's export trade and were valued at $\$ 23,647,194$ in foreign gold. Meanwhile, after 1901, the opening of Texas' mammoth oil fields enabled a new competitor to Standard Oil to emerge in Philadelphia. Joseph Pew (1848-1912), cofounder of Sun Oil, built a refinery in Marcus Hook, just outside the city in Delaware County, for refining and resale of Texas crude that his company shipped in coastal tankers to avoid railroads allied with Standard. Another upstart, Union Petroleum, also located at Marcus Hook. In this way, Philadelphia illustrated how even before the 1911 US Supreme Court decision that led to the breakup of Rockefeller's trust, competitors with links to newly discovered Gulf Coast fields were developing their own tanker fleets, pipeline networks, and refineries to cut into Standard's dominance of the East Coast and Atlantic petroleum trade. Although Philadelphia and New York reached the peak of their refinery production as early as 1891, their East Coast location ensured them an enduring 

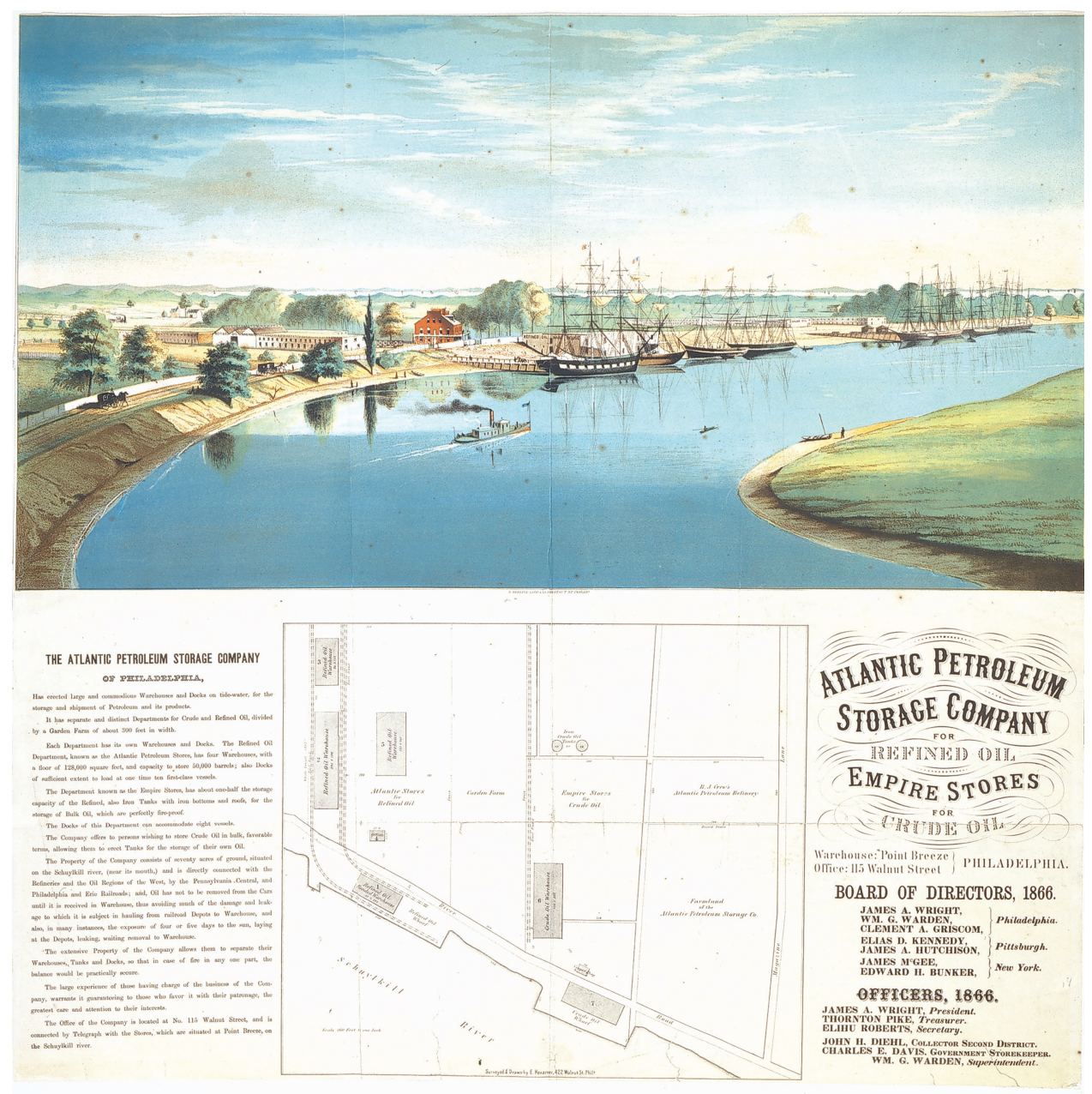

FIGURE 2.2 The Atlantic refinery on the Schuylkill River depicted as an idyllic location nestled among apple orchards. Atlantic Petroleum Storage Company Advertisement, 1866. Courtesy of the Library Company of Philadelphia.

role in the industry. The refineries at Marcus Hook became the basis for a new industrial cluster that included American Viscose, which located there in 1910, a steel mill in nearby Claymont, Delaware, and the Sun Oil Ship Building and Drydock Company (focused on tanker construction) in Chester in 1917. In the 1930s, Sun Oil built a pipeline from Western Pennsylvania to bring refined heating oil to market, further reinforcing the nodal character of Philadelphia and expanding the supporting infrastructure of the petroleumscape.

As Rockefeller and his rivals and critics understood, control of refineries, transportation, and distribution provided more leverage than control of oil fields themselves. Rockefeller's so-called Cleveland massacre of 1872, in which he and his partners acquired nearly all of northeastern Ohio's refining capacity, set in motion the relentless expansion that ended with the Standard Oil Trust in command of over 90 percent of the country's refining capacity at the height of its power. Despite increasingly fierce competition, on the eve of its 1911 
antitrust dissolution Standard Oil still processed around two-thirds of petroleum products across the US. Standard Oil leveraged its horizontal dominance of refining to construct a vertically integrated operation of enormous scale and scope, one that brought together all stages of the petroleum business (the so-called upstream, midstream, and downstream functions) over a huge geographic area. ${ }^{9}$ Standard Oil's integration of refineries, railways, and pipelines - captured in a widely circulated 1901 caricature of King Rockefeller with a crown of railways - are striking examples of the private control of infrastructure and the role of corporate capital in the creation of urban patterns and built form (Figure 2.3).

While Americans embraced Standard Oil's products, the company became profoundly unpopular, a byword for predatory capitalism. Indeed, the Rockefeller group's abuse of the legal device of the trust to tighten its grip on oil refining in the 1870s is the reason that Americans came to refer to anti-big business movements as antitrust. Caricatures of Rockefeller and cartoons about the threat of monopolistic oil helped to make the graphic arts a familiar part of the representational petroleumscape. Throughout the twentieth century, big oil recurred as a target for critical artistic commentary, for example, in the 1970s, when oil embargoes and gas shortages shattered trust in cheap energy, technology, and their supposedly unlimited potential. In the late twentieth century, artists and cartoonists in Europe and the US began to satirize and excoriate the oil industry's arrogance, along with the negative environmental impact of petroleum, even as in the Middle East a regionwide oil boom drew whole new populations into the lifestyles and ways of thinking associated with oil and gas consumption.

Administrative and research facilities emerged as a spatial petroleumscape distinct from oil's landscapes of production, transportation, and marketing. Oil companies supported

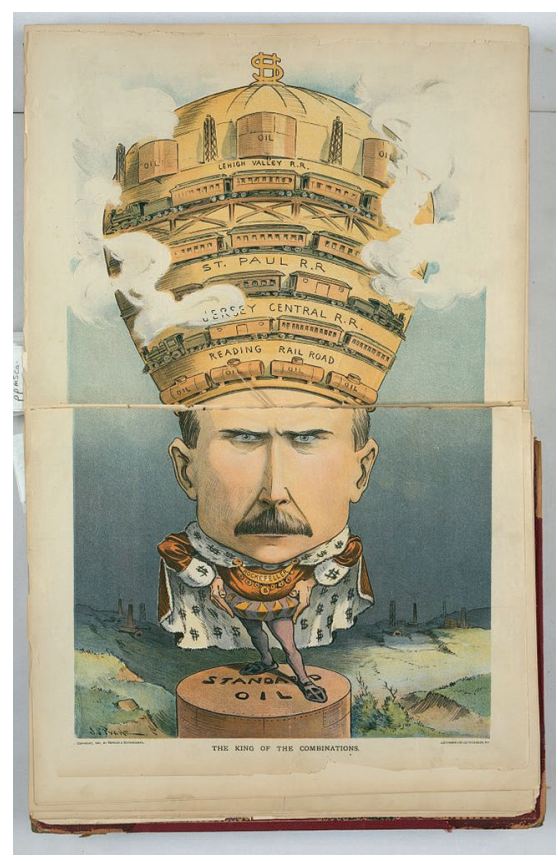

FIGURE 2.3 John D. Rockefeller, the "King of the Combination," Puck, February 21, 1901. Courtesy of Library of Congress: LC-DIG-ppmsca-25503. 
research and development, although at first this tended to be less institutionalized and systematic than the industrial research laboratories created by General Electric, AT\&T, and other electrical and telecommunications firms. By the 1910s-1920s, Standard Oil's successor firms, along with automobile companies, were investing in "cracking," anti-knock additives, and other innovations to increase the productivity and usefulness of gasoline for automobiles. And by the 1920s, chemical firms such as DuPont, Dow, and Union Carbide in the US, Imperial Chemical in Britain, and I.G. Farben in Germany were vigorously researching the use of petroleum by-products such as ethylene and propylene in plastics, synthetic materials, pharmaceuticals, dyes, paints, and explosives. By World War II, corporate-sponsored research in both private and academic settings - along with university training programs and professional associations in industrial chemistry and engineering-had become a significant manifestation of the petroleumscape. Although early plastics such as celluloid and bakelite could be made from coal tar and other organic chemicals and materials not necessarily derived from petroleum, DuPont's nylon, introduced in the 1930s, set the stage for the omnipresent postwar expansion of petrochemicals into domestic life and material culture. By the 1960s, the petroleumscape encompassed every household as well as people's bodies and everyday lives. ${ }^{10}$

Corporate offices became an especially visible dimension of the North American administrative petroleumscape. Oil's physical and financial flows intertwined, but their divergent spatial locations gave them a different presence on the landscape and in public consciousness. Oil administration buildings became distinctive urban and architectural spaces, their design in tune with that of other central city office buildings. Companies sited them in prestigious and strategic locations - in New York's financial district, for example, rather than Cleveland or Western Pennsylvania (Figure 2.4). In downtown Houston, the Texas Company (Texaco) headquarters, built in 1915, and Humble Oil's enormous complex, which came to fill an entire city block between 1919 and 1940, became major objects of civic pride, central to Houston's sense of heritage and eventually to its historic preservation efforts. Likewise, for most of the twentieth century, Dallas took as its symbol the enormous, red revolving Pegasus sign — the logo of Mobil Oil—placed in 1932 atop the 400-foot Magnolia Petroleum building, which was the tallest skyscraper west of the Mississippi when it opened in 1922 (Figure 2.5). ${ }^{11}$

The industry also created ancillary spaces, buildings not part of the production and business of oil. These included structures associated with housing, leisure, and the education of oil workers (managerial or working class). While often financed in full or in part by a company, they are rarely identified directly with the oil industry. As needed, corporations built entire neighborhoods or company towns. In West Texas, for example, settlements often began as hastily constructed barracks, boxcars, and trailers before evolving into oil towns, many of which then withered when the wells ran dry. ${ }^{12}$

In keeping with the country's customary emphasis on private civic activity, US petroleum interests have used philanthropy to leave their mark on cities and urban life, even as they exerted unabashed political influence to avoid taxes and regulation. Standard Oil founder John D. Rockefeller and his descendants sponsored educational, cultural, and health institutions, including the University of Chicago, Rockefeller University, and the Rockefeller Foundation. Meanwhile, Rockefeller Center (built 1931-1940), exemplifies the flow of oil wealth into commercial real estate, as do numerous residential subdivisions, hotels, and shopping centers from Houston to Los Angeles (Figure 2.6). 


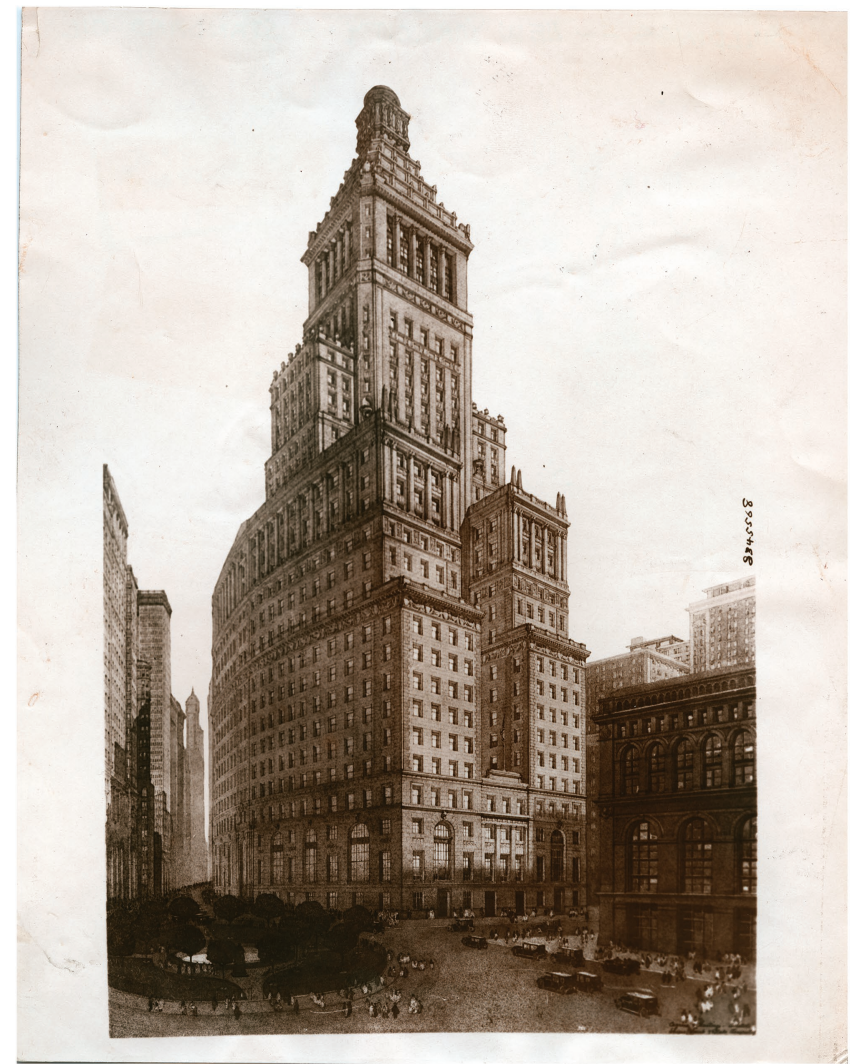

FIGURE 2.4 Architects' drawing from 1923 of the expanded Standard Oil headquarters at 26 Broadway, a well-known New York icon. Courtesy of Prints and Photographs, Library of Congress, Washington, DC, www.loc.gov/item/2014648263/.

\section{Gasoline, Pipelines, and the Energy West}

By the late 1800s, Standard Oil found itself beset with foreign competitors, such as the Dutch and British operations whose merger in 1907 created Royal Dutch Shell. European operators sought their own sources in Russia, the Dutch East Indies, and elsewhere. They created their own facilities at European ports, with the goal of limiting Standard Oil's presence in their domestic markets. They even asserted themselves in the US itself. Shell, for example, was an early backer of the Spindletop oil field near Beaumont, Texas, although the Pittsburgh-based Mellon family, whose Texas acquisitions around the same time became the basis for Gulf Oil, managed to push the Europeans out of the US oil fields for the time being (Figure 2.7).

From the start, the transformation of the US Southwest into the heart of the North American petroleumscape was connected to the corporate structures and multinational connections that had already come to characterize the petroleum's industry. The Texas oil business cultivated a self-image as a bastion of gruff, rebellious wildcatters resisting haughty East Coast capitalists. The lore of the Texas oilman as perpetuating the spirit of the Old West in the age of global capitalism and science-based industry-popularized by movies such as Giant (1956) and then recast into a garish soap opera by the series Dallas 


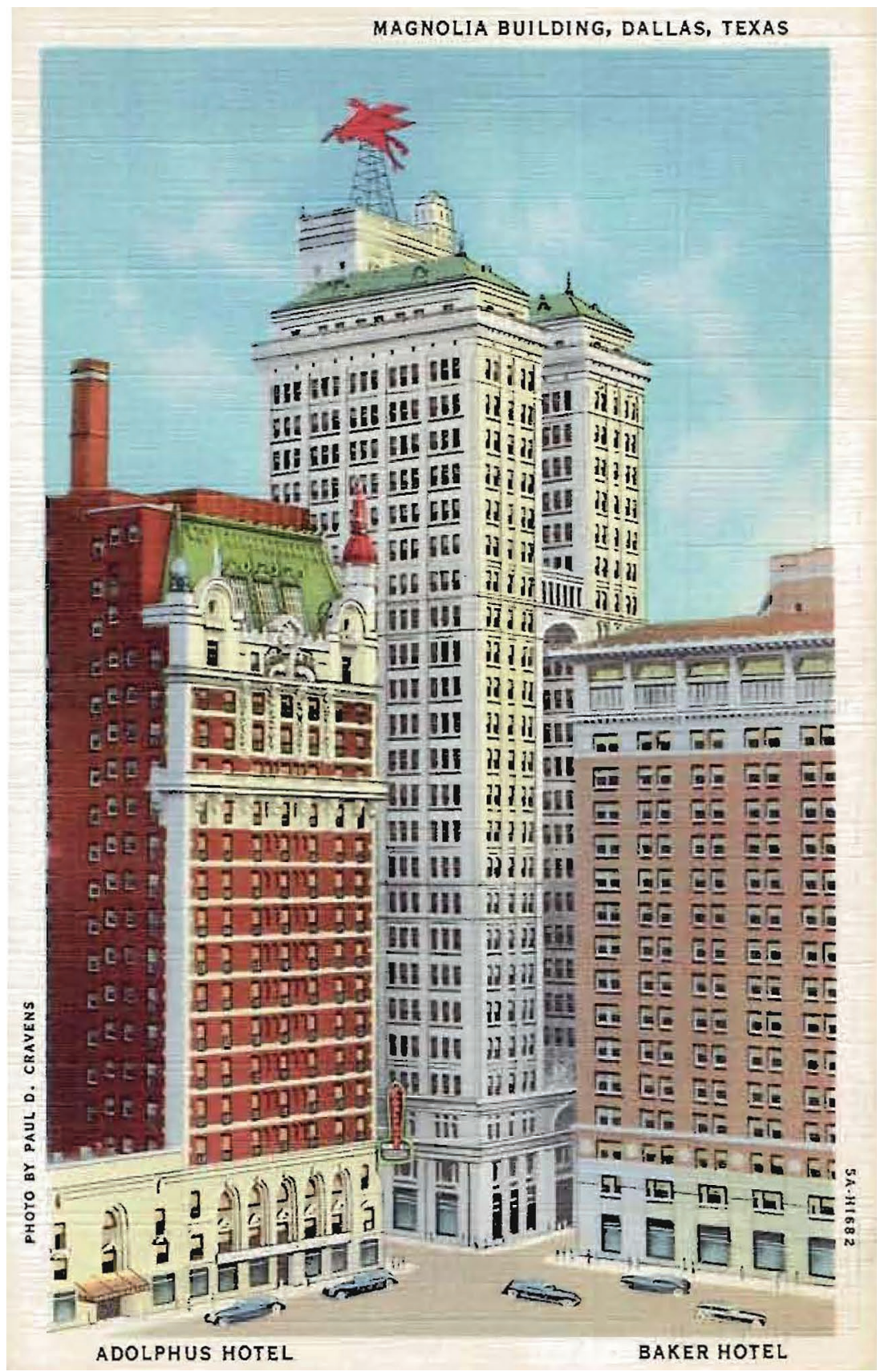

FIGURE 2.5 For over six decades, a giant rotating red neon image of Pegasus, symbol of SOCONY and later Mobil Oil, loomed over the Magnolia Building, Dallas' tallest skyscraper. Courtesy of American Oil and Gas Historical Society, https://www. aoghs.org/petroleum-art/high-flying-trademark/. 


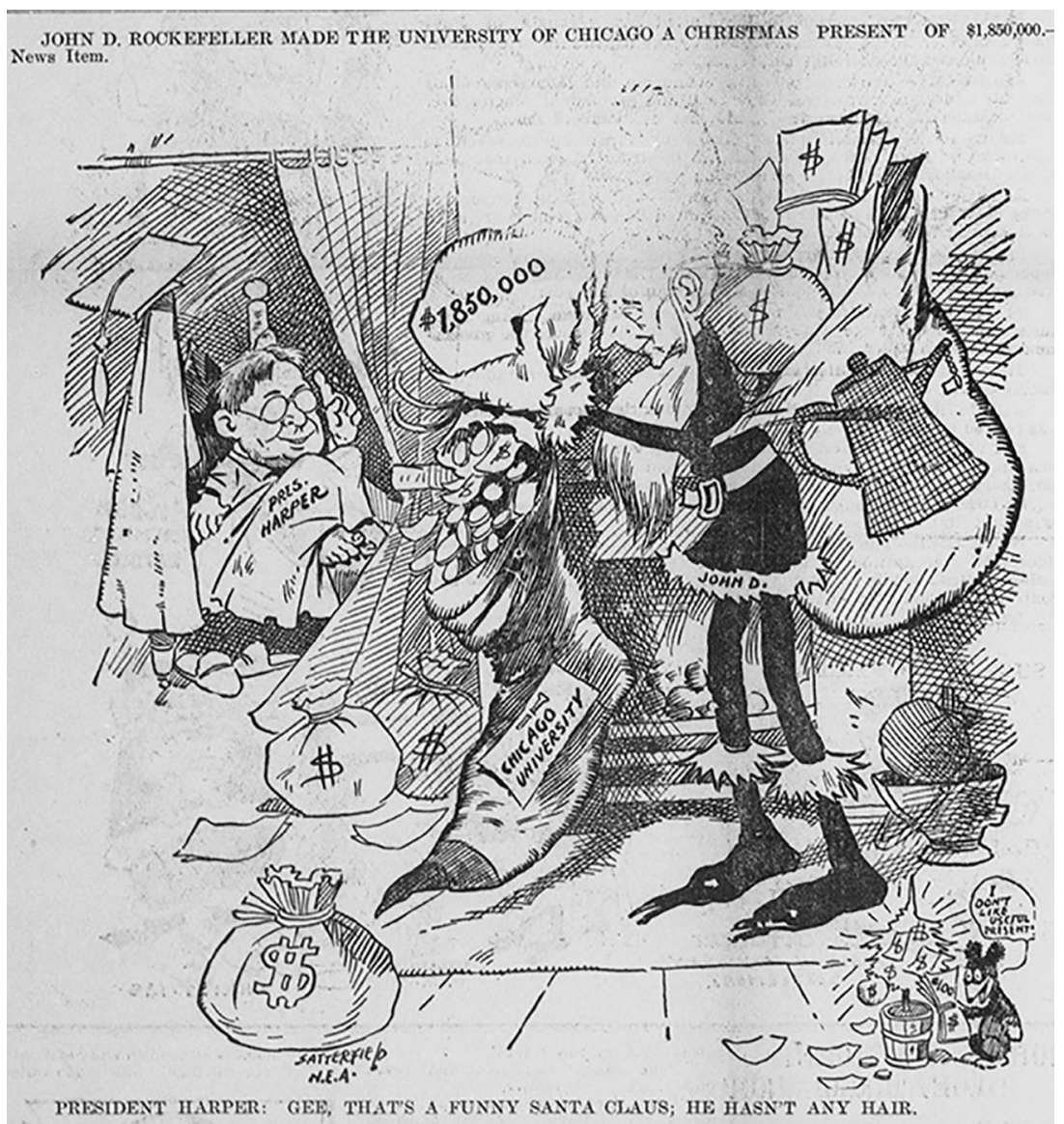

FIGURE 2.6 Cleveland News cartoonist Bob Satterfield portrayed John D. Rockefeller as Santa Claus delivering $\$ 1.85$ million to University of Chicago President William Rainey Harper, December 1903. Courtesy of Wikimedia Commons, https:// commons.wikimedia.org/wiki/File:Satterfield_cartoon_on_Rockefeller_gift_to_ University_of_Chicago_(1903).jpg.

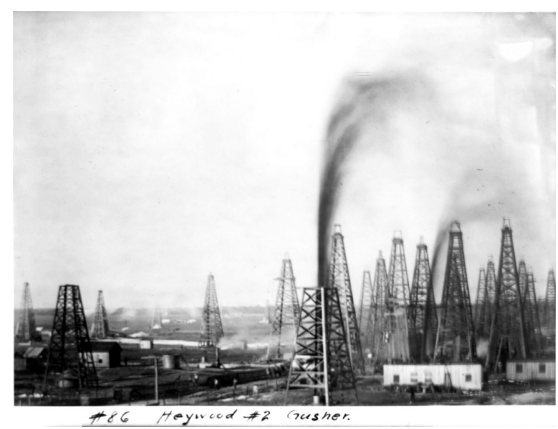

FIGURE 2.7 Heywood \#2 Gusher at the Spindletop oil field near Beaumont-Port Arthur, Texas, c. 1901. Courtesy of Prints and Photographs, Library of Congress, www.loc.gov/ pictures/item/2010649519/. 
(1978-1991) — had an element of reality. Even so, as with every western resource boom since the California Gold Rush of the 1840s, the Texas energy sector found that it needed East Coast capital and expertise to turn discoveries into steady profits. Both the Mellon family behind Gulf and the Pew family behind Sun had connections to the early oil and gas business in Western Pennsylvania. Joseph Cullinan, founder of Texaco, had managed pipelines for Standard Oil and run a Pennsylvania oil equipment company before investing in East Texas at the start of the boom there. And Magnolia Petroleum, originally a Texasowned firm active in the opening of the oil fields of West Texas and Oklahoma, only remained independent until 1916, when it was jointly acquired by Standard Oil of New York and Standard Oil of New Jersey. ${ }^{13}$

Nevertheless, a striking aspect of the Texas oil boom was the ability of Houston and DallasFort Worth to draw on outside capital and expertise and yet retain ample earnings. Capital generated by oil became the basis for a homegrown energy industry, for diversified regional economies, and for universities, museums, research institutes, and other cultural components of dynamic, autonomous urban regions. The Texas experience thus provides a sharp counterexample to the so-called curse of oil, the reputation of this form of resource extraction for consigning its sources to neocolonial status. A factor in this ability to turn an oil boom into durable wealth was the unusual level of solidarity among Houston and Dallas business and civic elites. The business and professional classes in these and other Texas cities put together oligarchic, pro-growth governing coalitions that maintained control of the major Texas and southwestern cities during their formative periods. The cohesiveness of commercial-civic rule in Dallas or Houston was to some degree a product of the desire among urban business classes in the Southwest to avoid the sort of internal colonial dependence on northeastern capital, expertise, and control that seemed to weigh upon the post-Reconstruction South. ${ }^{14}$

Oil production spread to Texas, Oklahoma, and California while fossil fuels and petroleum products became more pervasive aspects of modern industry and life. The initial discoveries in East Texas at the start of the twentieth century produced vast quantities of crude oil and natural gas. Not much of the East Texas oil was of the quality needed for kerosene, still petroleum's main use. But it was good enough to power the oil-fired engines increasingly adopted by railroads and steamship companies. The adoption of oil power by industries ranging from brickyards to breweries accelerated the emergence of industrial sectors in cities such as Houston and Los Angeles. Likewise, oil furnaces began to replace coal in household heating. This was apart from the massive new demand for gasoline. Initially an unwanted by-product of refining for kerosene, gasoline became valuable by the early 1900s, when the internal combustion engine outpaced steam and electricity as motive power for automobiles. Over the next two decades, innovations in refining and in processing made gasoline an increasingly important part of the oil industry, even as the spread of electric lighting reduced demand for kerosene. ${ }^{15}$

The Pennsylvanians brought to Texas an understanding of the potential of natural gas, a pervasive presence in oil fields, but one often regarded by drillers as a dangerous nuisance to be burned off. The Pews, for example, had first become well-known through an effort in the 1880s to supply Pittsburgh with natural gas as a substitute for the manufactured coal gas that fueled early gas lighting systems. By the mid-1880s, Standard Oil, which initially began constructing pipelines from oil fields as an alternative to dependence on railroads, had made its own investments in pipelines for natural gas, first as an industrial fuel and later for domestic uses. As soon as western oil fields began to open, cities as far-flung as Kansas City and Denver welcomed natural gas pipelines as a cleaner alternative to the coal gas monopolies resented by many urban residents. Natural gas overtook manufactured gas 
in the 1920s-1930s, by which time the Southwest outproduced Appalachia, the first source for the fuel, by a factor of 4-1. The strategic character of gas and oil pipelines as well as a series of political scandals prompted the federal government, along with producing states such as California, Oklahoma, and Texas, to extend regulatory authority over them. The Texas Railroad Commission, which gained oversight of petroleum fields and oil and gas pipelines in 1917-1919, became a lever that Texas interests used to ensure that they and not "foreigners" profited from the state's energy resources. The New Deal era and then World War II prompted the federal government to expand its regulation of the gas and oil pipelines, which had come to span the continent. Federal and state regulators gained sway over the routes of pipelines, the quantity and quality of gas, its allocation, and its price (Figure 2.8). ${ }^{16}$

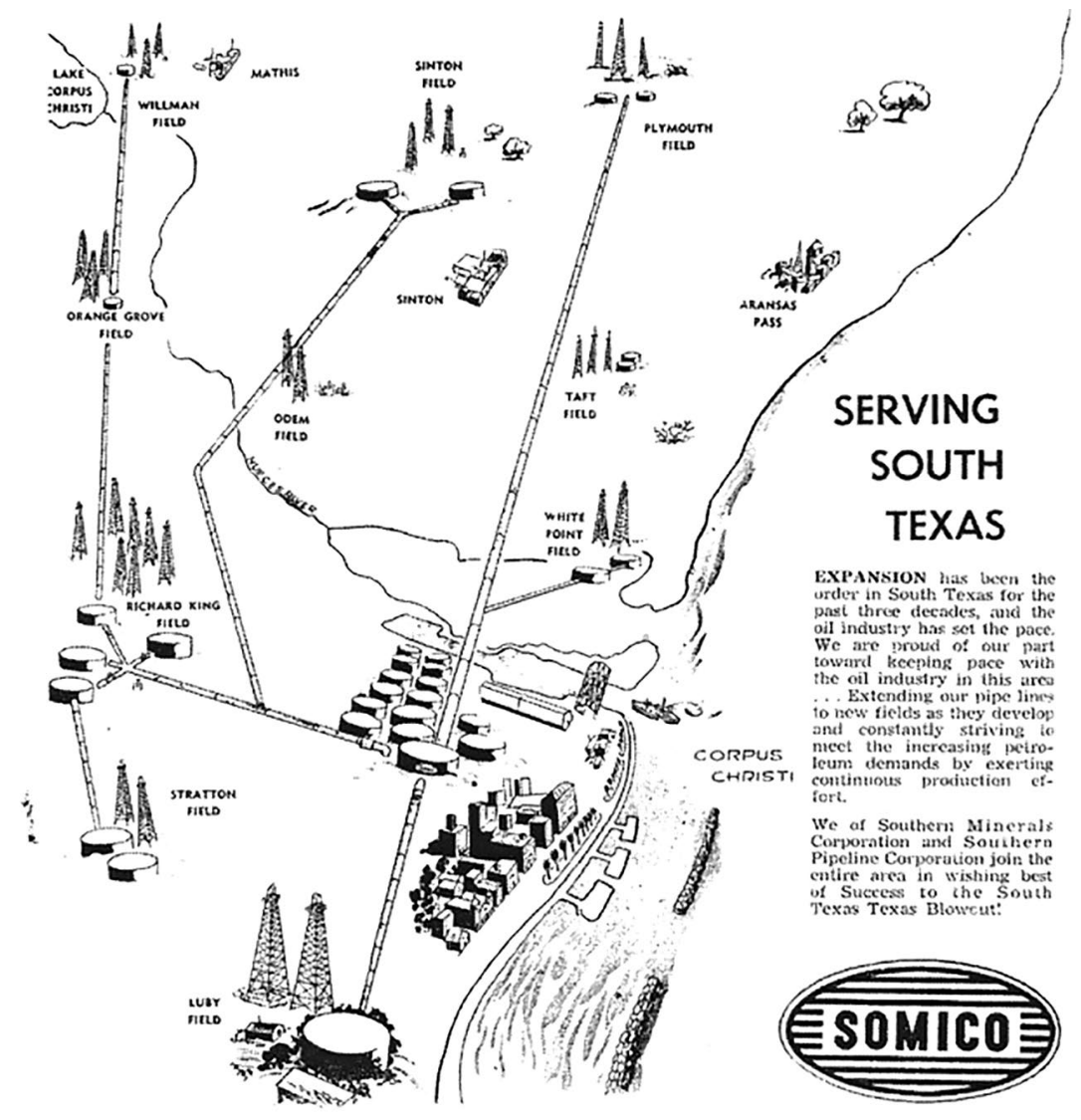

\section{Southern Minerals Corporation - Southern Pipe Line Corporation \\ CORPUS CHRISTI}

FIGURE 2.8 Advertisement for the Southern Minerals Corporation (SOMICO) in an oil industry convention brochure, 1951. Founded in the 1930s to supply natural gas to high-energy industries then locating around the Corpus Christi Ship Channel, SOMICO illustrates how Texas' petroleum sector promoted regional industrial diversification. Courtesy of Kilgore Collection, Special Collections, Texas A\&M University-Corpus Christi. 


\section{The Texas Coast: From Waterscape to Petroleumscape}

Starting in the early twentieth century, the Gulf Coast witnessed a massive reengineering of land and water in the service of oil and gas. In 1896, the US Congress authorized the dredging of Buffalo Bayou, the slow-moving river that runs through Houston into Galveston Bay. The goal was to transform the shallow bayou into a deep channel navigable by ocean-going ships. At that time, the project was understood as a recognition that inland ports-with their ample land for rail connections, freight yards, and industrial sites-were becoming more viable for industrial-era commerce than traditional ocean-side ports such as Galveston. Besides being vulnerable to catastrophes such as the horrific Hurricane of 1900 (to this day, the deadliest natural disaster in US history), Galveston, a long, thin barrier island two miles off the mainland, had limited space for railroads, freight, and factories, along with limited supplies of fresh water. As with the Manchester Ship Canal and Chicago's Sanitary and Ship Canal, the Houston Ship Channel reflected a new understanding among urban commercial interests that industry and railroads had overturned the traditional logic of harbor location. Counterintuitively, it now made more sense to bring ships inland to industrial complexes, railroads, and freight yards than to bring all that to the sea.

By the time the fifty-two-mile Houston Ship Channel opened in 1914, pipelines, storage tanks, and refineries had become more relevant than the cotton gins, grain elevators, and other agricultural operations that the Port of Houston was initially envisioned as specializing in. Seventeen railroads met at Houston, the city where Gulf, Sun, Texaco, and other post-Spindletop producers concentrated their operations. Nine refineries lined the ship channel by 1930, while gas and oil pipelines began to attract high-energy-using industries: cement and fertilizer works, metals manufacturers, and both organic and inorganic chemical plants. Already by 1950 , twenty-seven chemical plants lined the Houston Ship Channel, a trend that continued over the next decades, until the ship channel emerged as the country's largest petrochemical complex (Figure 2.9). The larger area stretching from Houston to Beaumont contained over half the country's petrochemical capacity by the 1980s. Houston also became the center for oil equipment manufacturers such as Hughes Tools, founded by Howard Hughes Sr., father of the billionaire adventurer. Houston-based construction firms such as Brown and Root innovated methods for constructing pipelines, petrochemical plants, and offshore oil platforms. Beyond its unparalleled transportation and storage facilities, therefore, Houston offered a comprehensive aggregation of support industries and technical and business services to the energy sector. The city became the country's - and eventually the world's - energy capital because the sector's knowledge economy concentrated there, in exploration, drilling, logistics, and refining. ${ }^{17}$

By the mid-twentieth century, the Port of Houston had become what environmental historian Christopher Sellers calls a "petropolis." An autonomous jurisdiction under the authority of the Port of Houston Authority, the port stretched twenty-five miles, about half the total length of the Houston Ship Channel. The enormous zone covered by refineries, storage tanks, and chemical factories provided unforgettable urban vistas, comparable to the skylines of New York or Chicago. Refinery towers and columns, writes the architectural historian Barrie Scardino Bradley:

gleam in the sunlight, just as they shine with lights at night, offering a picture of a contained, surreal city the way medieval pilgrims must have found the seventy-two towers of San Gimigano in Italy rising out of the land. ${ }^{18}$ 

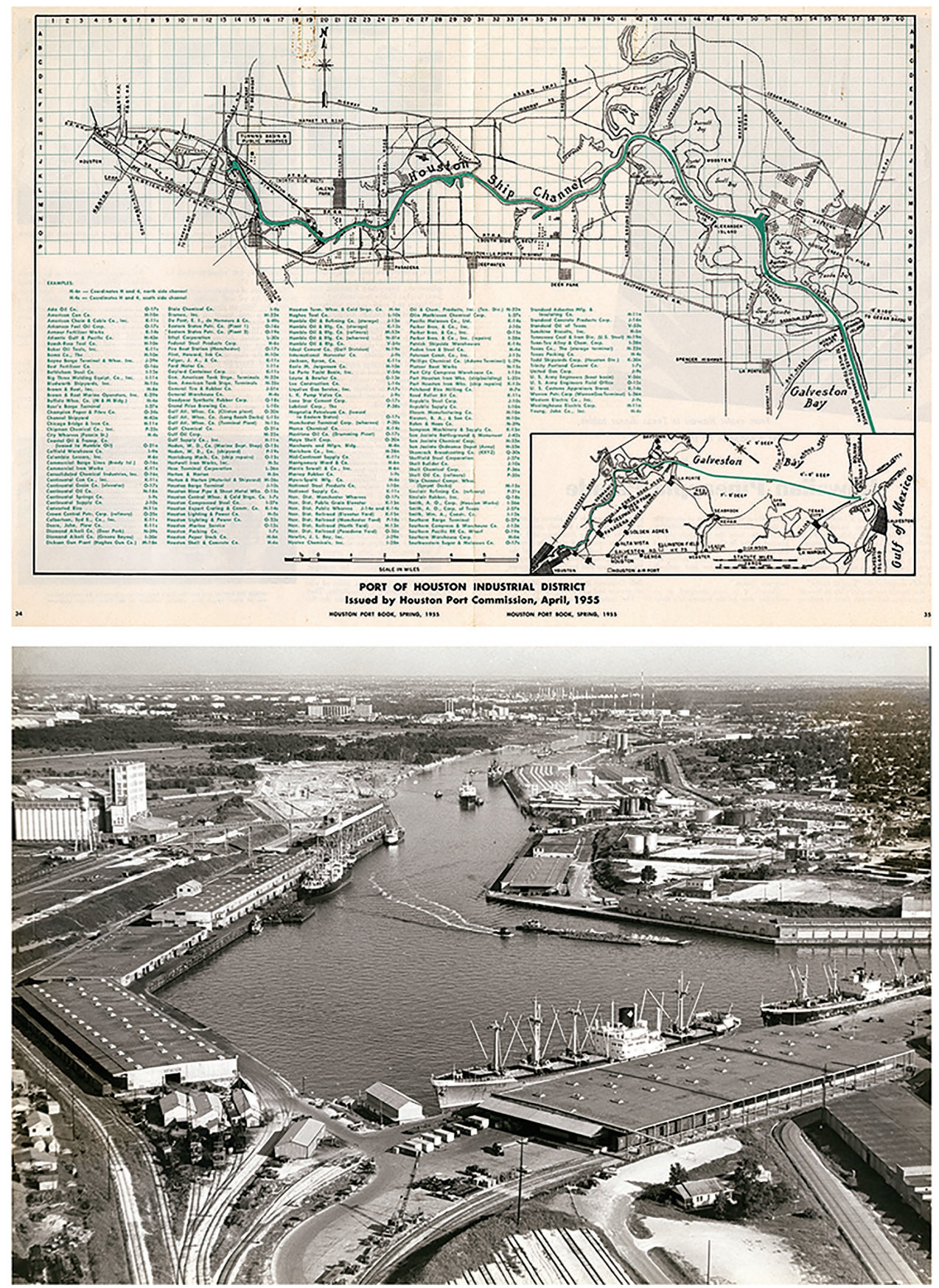

FIGURE 2.9 Map of the fifty-two-mile Houston Ship Channel (a), along with bird's-eye view of the ship channel's turning basin, mid-1950s (b), by the mid-twentieth century, the focal point of the North American petroleum and petrochemical industries. Courtesy of University of Houston Digital Library. 
Almost no one lived within the Port Authority's city of petroleum and petrochemicals. In Houston and other burgeoning Texas metropolises, energy companies could leave the ancillary city of houses, shopping, and entertainment to real estate developers. White migrants from Texas and the southern US flowed into ramshackle neighborhoods on either side of the ship channel, eager for steady pay and skilled work offered at the port and its industries. The renowned songwriter Rodney Crowell recalls that in the last months of World War II, his maternal grandparents quit sharecropping in West Tennessee and made their way with his mother to Houston, where his grandfather was thrilled to find a "twenty-sevendollar-a-week night watchman job" at Hughes Tool. Shortly thereafter, they were joined by Crowell's father, a troubled seventh grade dropout and disappointed country musician who had grown up in Arkansas and Kentucky. In 1955, Crowell's parents moved from a rented house on Avenue P, three blocks south of the ship channel, to Norvic Street in the workingclass suburb of Jacinto City, about five miles to the ship channel's north (Figure 2.10). The neighborhood, Crowell recalls, was filled with "cookie-cutter bungalows whose poor workmanship, lack of imagination, and cheap materials destined them for an early demise," but were nonetheless "barely affordable to the workforce employed by the refineries and chemical plants lining the ship channel like so many poison gas spewing space stations."19

African Americans and Mexican Americans also sought opportunities in the oil-and-gas ports of the Gulf Coast, even though labor market segregation confined these groups to the least skilled and most dangerous jobs until the 1960s-1970s. In Houston, diverse and dynamic Black and Latino neighborhoods emerged around the sprawling city, including in the Second and Fifth Wards on either side of the ship channel. In Corpus Christi, the Tejano

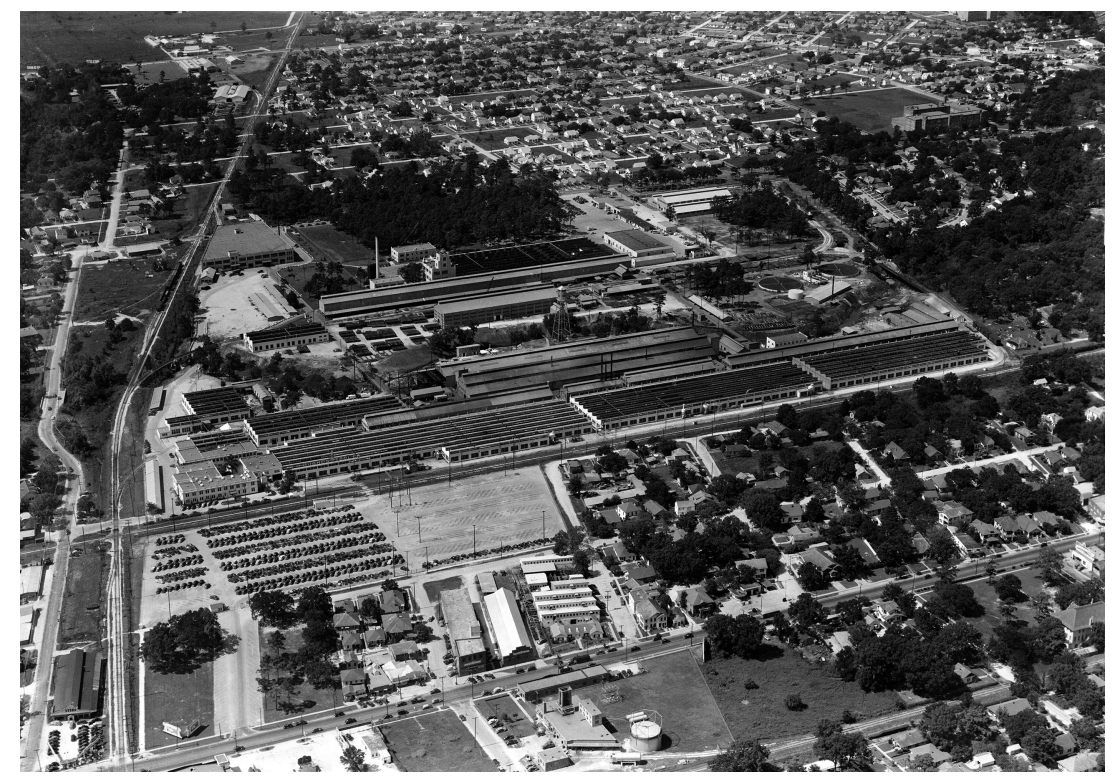

FIGURE 2.10 Aerial photo of Houston's Hughes Tool plant, 1941, a famed example of the numerous oil industry equipment firms located along the Houston Ship Channel. Such firms attracted migrants from small towns and rural areas across Texas and the South. Courtesy of Bob Bailey Studios Photograph Collection, e_bb_3158, Dolph Briscoe Center for American History, University of Texas at Austin. 
barrio stretched across the Westside to the edge of that city's ship channel, while the African American Northside expanded into formerly Anglo American neighborhoods such as Hillcrest, whose proximity to refineries accelerated white flight from the area. The proximity of Black and Hispanic neighborhoods to one another and to the port and its industries helped these groups to some degree overcome mutual suspicions and job market competition to cooperate in labor union organizing and in anti-segregation and civil rights activism. ${ }^{20}$ (Fuccaro, this volume, discusses diverse streams of labor that flowed to oil towns in Kuwait and other parts of the Middle East and the political complexity that arose, despite corporate power that pushed a more uniformly celebratory view.)

Two hundred miles to Houston's south, Corpus Christi exemplifies how the opening of more and more oil fields in the decades after Spindletop catalyzed the reconstruction of much of coastal Texas into petroleumscape. In 1919, a terrifying hurricane and storm surge hit this portion of the South Texas coast. Similar to how the 1900 Galveston storm affected the Houston Ship Channel debate two decades earlier, this catastrophe convinced Texas and federal officials to dredge a ship channel twenty miles from the Texas barrier islands across shallow Corpus Christi Bay to a protected turning basin at Corpus Christi, then a coastal town of around 10,000 people, where four railroads already met. When it opened with much fanfare in 1926, the Port of Corpus Christi was-again similar to Houston-initially envisioned as an outlet for South Texas cotton, grain, and cattle. But oil and gas discoveries throughout the city's hinterland soon shifted the port toward oil and petrochemicals. By the 1960s, five refineries were located along the ship channel as well as organic and inorganic chemical producers, metals manufacturers, and food processors drawn by natural gas pipelines and the promise of ample freshwater supplies. Corpus Christi's autonomous Port Authority repeatedly extended and deepened the channel, until it reached thirty-four nautical miles and a depth of forty-two feet. Corpus Christi developed its own equipment construction and other support businesses, although control of these over time concentrated

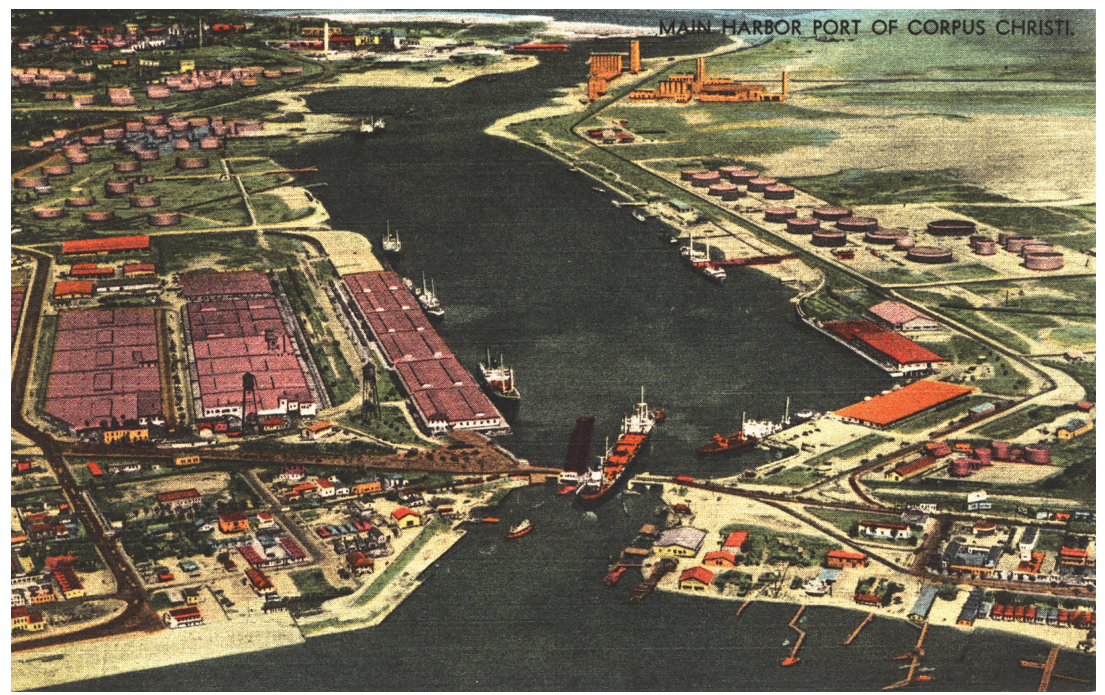

FIGURE 2.11 Aerial postcard of the Corpus Christi Ship Channel in the 1940s. Envisioned as an outlet for South Texas agriculture, it became dominated by oil and gas and by high-energy industries starting in the 1930s. Courtesy of Corpus Christi Public Library. 
in Houston, as did specialized services such as petroleum geology. This movement of professional and technical services as well as management from Corpus Christi to Houston especially, but also to San Antonio and even Wichita, Kansas (home of Koch Industries, which came to own much of Corpus Christi's energy sector), reduced the Texas coast's second most important port to the status of a satellite of the US West's energy capitals (Figure 2.11). ${ }^{21}$

\section{The Representational Petroleumscape of Extractive Empire}

As in Texas, southern California's emergence as an energy metropole appears in literature and lore as an updating of the region's frontier and pioneer self-image, with oil a successor in spirit to the gold and land rushes of the mid-1800s. Upton Sinclair's Oil! (1926) and the film loosely based on it, There Will Be Blood (2007), capture much of this atmosphere. As in Houston, the reengineering of Los Angeles's port at San Pedro began not with oil but with California agricultural products. The southern California oil boom that began in the 1890s led to rigs on beaches, in parks, and even in residential neighborhoods. It also became the foundation for Los Angeles as the archetype of distended, multicentered metropolis, with its subdivisions of bungalows and ranch houses that stretch through valleys and into former orchards. The residential Los Angeles of the Anglo middle class hinged on a network of petroleum-based industrial suburbs, which were more diverse in class and ethnicity than Southern California's archetypal residential suburbs, but they barely registered in Los Angeles's self-promotion or public image. ${ }^{22}$

Beyond serving as an archetype for the petroleumscape's urban form, Los Angeles became a launching point for another group of operators who extended the US petroleumscape outward through the Americas. Edward Doheny, the Irish American surveyor and itinerant prospector on whom Sinclair's protagonist was loosely based, expanded the US presence in oil fields near Tampico, Mexico, starting in 1901. Doheny held on to his Mexican interests through the twists and turns of the Mexican Revolution that began with the overthrow of Porfirio Díaz's regime in 1911 (Figure 2.12). By the time Mexico expropriated and nationalized foreign operations in the country in 1938, about 65 percent of its production was controlled by Royal Dutch/Shell, with US companies controlling most of the rest. Foreign companies hurriedly withdrew families from their complexes in the Tampico region. Well-maintained towns for expatriate managers and engineers surrounded by poorly built and poorly serviced settlements for local workers had already become a recognizable urban manifestation of the oil industry's

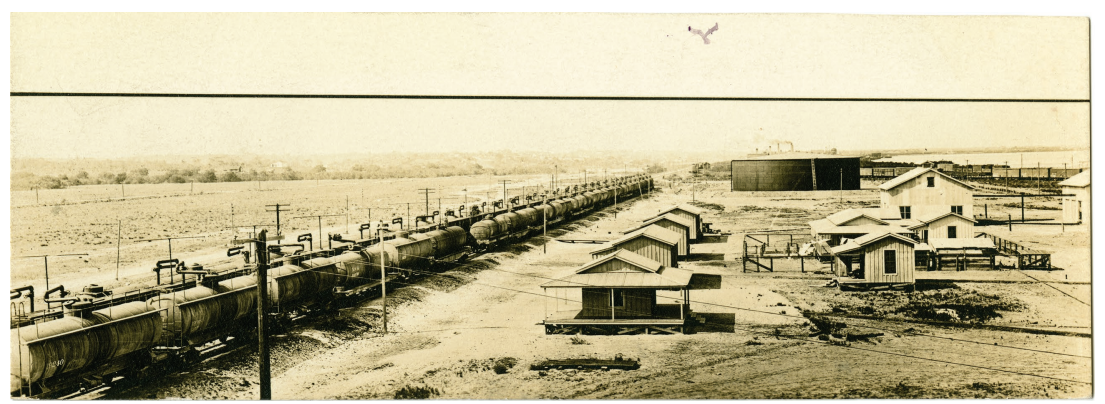

FIGURE 2.12 Oil tank cars at loading docks in Tampico, Mexico, 1910s. Courtesy of HazardDyson Collection Eberstadt Collection, e_enr_050, the Dolph Briscoe Center for American History, the University of Texas at Austin. 
transnational dimensions. Although incensed by Mexican nationalization of their holdings, European and American oil operators grudgingly accepted their ouster from the country, in part because they had already developed an alternative set of fields in Venezuela. ${ }^{23}$

In sum, the North American petroleumscape-including that in Mexico and Canadacame to incorporate and perpetuate an older reality about the American West, its tendency to grow as offshoots or hinterlands of either a Greater California or a Greater Texas. Houston, Dallas, and Oklahoma oil millionaires, for example, underwrote and oversaw the formation of Colorado's energy sector in the 1950s, to the extent of putting up the funds for Denver bank buildings, corporate offices, and even that city's Petroleum Club. As geographer D.W. Meinig remarked in 1969, oil brought Texas a new "cultural self-consciousness and commercial imperialism." Houston-based producers and processors, equipment manufacturers, and suppliers had made "oil districts far beyond the bounds of Texas" into extensions of Houston's energy sector. Even the oil fields of Alberta grew initially as manifestations of US-based enterprise. Until the late twentieth century-when Canadian and provincial authorities succeeded in shifting much of the city's energy sector toward locally controlled independents-Calgary had replicated Denver's role as a "junior headquarters energy capital” for "international oil majors," while Canadian-owned companies gravitated toward the provincial capital, Edmonton. ${ }^{24}$

Even more than Alberta's, Louisiana's energy sector took shape as a dependency of New York or Texas enterprise, an extension of the original administrative petroleumscape. The extractive internal colonialism that Louisiana experienced prefigured and mirrored the extractive neocolonial petroleumscape that the petroleum business spread to much of the world (Figure 2.13). The story can be told through the life and legend of Huey Long, recounted in song, art, and film as well as literature in the case of Robert Penn Warren's great novel All the King's Men (1947). Exploitation by Standard Oil and other corporate interests-backed by a pliable New Orleans and Baton Rouge political establishmentmade the state susceptible to Long's style of demagogic resentment, political brutality, and garish corruption. By the 1920s, when Long became his state's dominant political figure,

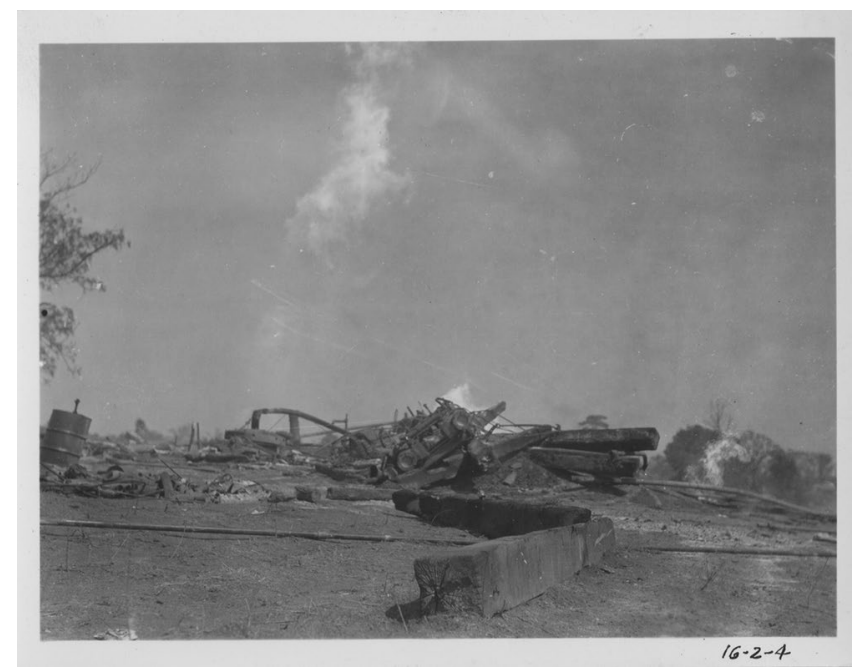

FIGURE 2.13 Well debris in DeSoto Parish, Louisiana, 1925. Environmental devastation quickly became a source of resentment and political tension in Louisiana. Courtesy of the Photograph Collection, State Library of Louisiana. 
the sense was widespread that Louisiana had been abandoned to the environmental degradation and class exploitation associated with the oil industry. Outrageously favorable leasing and tax arrangements and other favors and concessions meant that oil brought most residents few benefits in terms of improved public services, education, or opportunities.

Drillers found oil in the vicinity of Lafayette and Shreveport, Louisiana, in the early 1900s, not long after the strikes over the Sabine River in East Texas. By the 1920s, supplies had been discovered across southern Louisiana. In 1909, meanwhile, Standard Oil began constructing a large refinery above the Mississippi near Baton Rouge; a pipeline from Oklahoma fed this plant even before it began to draw from nearby fields. The Baton Rouge location gave the company "no little satisfaction," as a detailed history of the company remarks, since Standard thereby sidestepped the "ill will" and state regulation that hampered it in Texas. Two more refineries were constructed closer to New Orleans before the Great Depression. Then, in the postwar era, the federal government, needing aviation fuel, synthetic rubber, and other petroleum products, subsidized refining and petrochemical facilities in stretches along the lower Mississippi. ${ }^{25}$

As in Texas, chemical plants and metals manufacturers followed, so that by 1947, Louisiana contained twenty-five refineries and 147 chemical operations (Figure 2.14). Most were located in struggling agricultural areas, disproportionately inhabited by African Americans. The so-called Chemical Corridor between Baton Rouge and New Orleans occupied former sugar plantation regions, resulting in the jarring spectacle of rundown plantation houses - relic of an earlier extractive economy-scattered among toxic dumps and factories spewing smoke. Portions of the lower Mississippi degraded into what geographer Craig Colten labeled a sacrifice zone, where "negligent behavior by industry and government authorities" came to seem tolerable. The area became notorious for chemical plant explosions, toxic leaks, groundwater contamination, and toxic dumping, though the threat to fisheries and urban water supplies did prompt efforts to limit discharges into rivers. ${ }^{26}$

Starting in the 1940s, the spread of the oil industry to offshore platforms created tensions involving Louisiana's shrimping and fishing industry. Local officials attempted to reconcile these tensions, at least symbolically, for example, by recasting Morgan City's Shrimp Festival as the Shrimp and Petroleum Festival, starting in 1967. The environmental scholar Barbara Allen, a native of Morgan City, observes that Louisiana's Chemical Corridor produced 12.5 percent of the country's hazardous waste by the late twentieth century, "sixteen thousand pounds of hazardous waste for every citizen in the state." Even before the 2010 BP/Deepwater Horizon spill, which brought worldwide attention to the petroleum-induced devastation of the Mississippi Delta and the Gulf, Louisiana was a center for environmental justice activism "against multinational corporations and their close allies, Louisiana's regulatory agencies," Allen remarks. Still, what another environmental scholar Ashley Dawson labels "petro-governance" remained difficult to counter. Even after Hurricane Katrina in 2005 and then the BP disaster in 2010, oil and petrochemical companies, determined to protect their networks of pipelines, storage tanks, and production facilities, resisted coastal and wetlands restoration measures that might enable New Orleans and lower Louisiana even minimally to adjust to global warming - which is, of course, induced by the very activities that are also degrading the Mississippi Delta and the Gulf. ${ }^{27}$

As the business of producing, processing, transporting, and marketing petroleum spread across the North American continent, it brought about epic geographic and environmental changes. Parallel changes took place in people's homes, routines, and material culture. Home appliances, advertising and public relations, roadside attractions, gas stations, freeways, traffic lights, and parking lots extended the petroleumscape into every aspect of society and made 

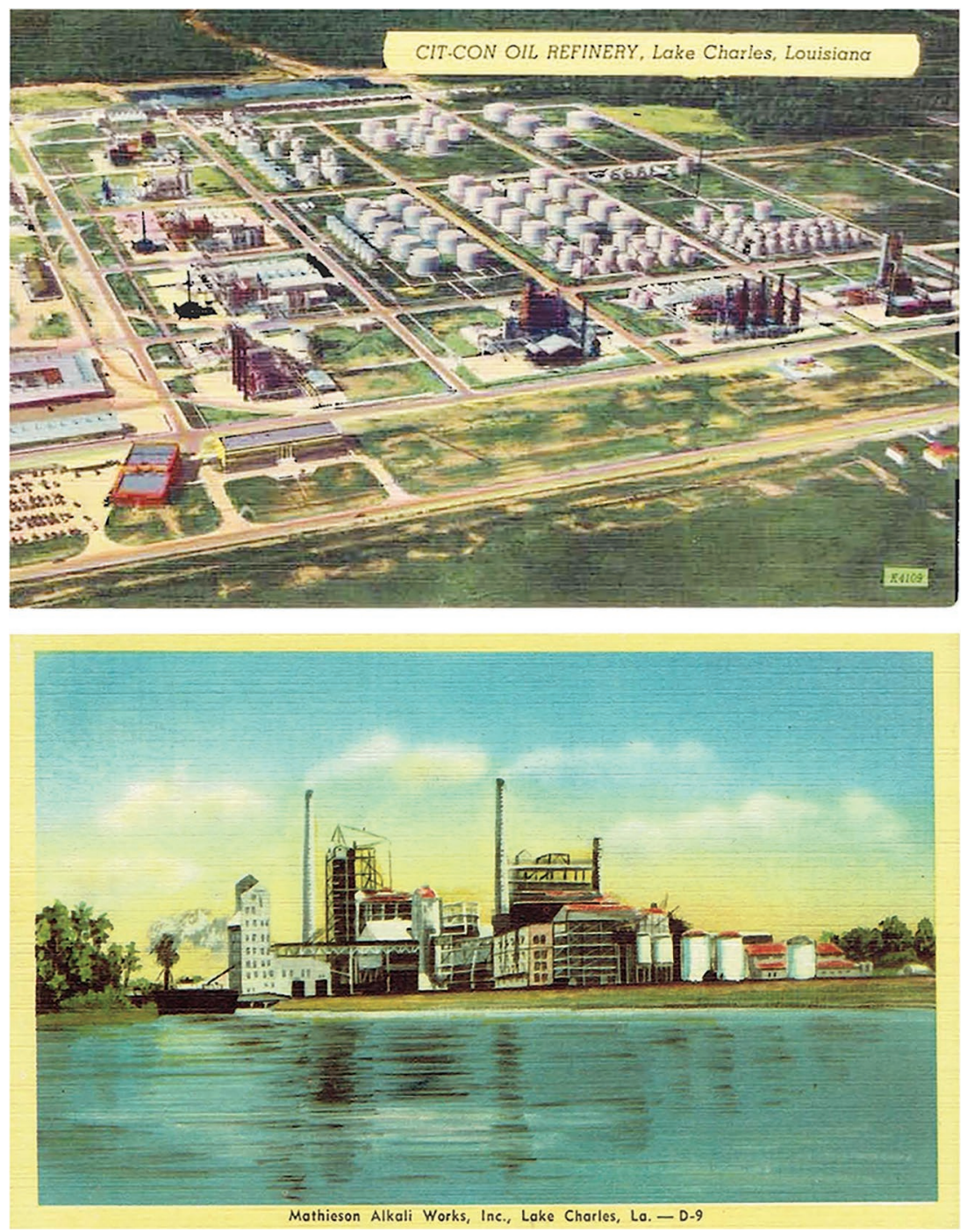

FIGURE 2.14 1940s postcards of the Cit-Con Oil Refinery (a) and the Mathiesen Alkali Works, Lake Charles, Louisiana (b). The spread of petroleum refining, petrochemicals, and high-energy-using industries complicated efforts at waterway protection, coastal restoration, and storm and flood control. Reference courtesy of Historic Photographs of Southwest Louisiana, Frazer Memorial Library, McNeese State University.

fossil fuels seem inexorable and inescapable, a future from which there could be no turning back. Americans interact with the constructed landscape of fossil fuels as though there is no alternative. Usually, they treat it as though it is hardly there, in a manner akin to the fish in David Foster Wallace's well-known speech “This is Water." When confronted with the fact that they swim in water, they respond mystified, "What the hell is water?" The story's lesson-that "obvious, important realities" can be "hardest to see and talk about"-is "just a banal platitude," Wallace concedes. But, he adds, "banal platitudes can have life or death importance." ${ }^{28}$ Having remade itself over the century covered by this chapter into an empire 
of oil and gas, a nation organized around and defined by fossil fuels, the US may be the most daunting socio-political challenge of the worldwide environmental crisis. Its petroleumscape is a massive obstacle in the way of the pressing necessity of switching energy paths.

\section{Notes}

1 Carola Hein, "Oil Spaces: The Global Petroleumscape in the Rotterdam/the Hague Area," Journal of Urban History 44 (September 2018): 887-929; Carola Hein, "Between Oil and Water: The Logistical Petroleumscape," in The Petropolis of Tomorrow, eds. Neeraj Bhatia and Mary Casper (Houston: Actar/ Architecture at Rice, 2013), 436-47; Carola Hein, "Global Landscapes of Oil," New Geographies 02: Landscapes of Energy, ed. Rania Ghosn (Cambridge: Harvard University Press, 2009), 33-42.

2 Joel Tarr and Karen Clay, "Pittsburgh as an Energy Capital," in Energy Capitals: Local Influence, Global Impact, eds. Joseph A. Pratt, Martin V. Melosi, and Kathleen A. Brosnan (Pittsburgh, PA: University of Pittsburgh Press, 2014), 5-29; Christopher Jones, Routes of Power: Energy and Modern America (Cambridge: Harvard University Press, 2014), ch. 1-2.

3 Carl Abbott, How Cities Won the West: Four Centuries of Urban Change in Western North America (Albuquerque: University of New Mexico Press, 2008), 248.

4 Ida M. Tarbell, The History of the Standard Oil Company (New York: Peter Smith, 1950[1904]), 32ff.; Daniel Yergin, The Prize: The Epic Quest for Oil, Money, and Power (New York: Free Press 2009), 30; Ralph W. Hidy and Muriel Hidy, History of Standard Oil Company (New Jersey): Pioneering in Big Business (New York: Harper \& Brothers, 1955), 101, 123-24; Jones, Routes of Power, ch. 3-4.

5 Carola Hein, "Refineries (Oil)," Encyclopedia of Greater Philadelphia, philadelphiaencyclopedia. org/archive/refineries-oil/\#22535, accessed June 20, 2020; Carola Hein and Dirk Schubert, "Resilience and Path Dependence: A Comparative Study of the Port Cities of London, Hamburg, and Philadelphia," Journal of Urban History 47, no. 2: 389-419. Article first published online: June 11, 2020; Issue published: March 1, 2021, https://doi.org/10.1177/0096144220925098; Nathaniel Burt and Wallace C. Davies, "The Iron Age, 1876-1905," in Philadelphia: A 300-Year History, ed. Russell F. Weigley (New York: Norton, 1982), 471-523; Philip Scranton and Walter K. Licht, Work Sights: Industrial Philadelphia, 1890-1950 (Philadelphia, PA: Temple University Press, 1986).

6 "Our Oil Trade, Petroleum the Rival of King Cotton," Philadelphia Inquirer, October 16, 1867, 5; "Struck Oil, A Great Fire at Point Breeze," Philadelphia North American, June 12, 1879, 1.

7 Ron Chernow, Titan: The Life of John D. Rockefeller (New York: Random House, 1998), 171; Grant Segall, John D. Rockefeller: Anointed with Oil (Oxford: Oxford University Press, 2001), 57-58; Albert J. Churella, The Pennsylvania Railroad, Vol. 1: Building an Empire, 1846-1917 (Philadelphia: University of Pennsylvania Press, 2012), 359ff.

8 Burt and Davies, "Iron Age," 482-83; Hidy and Hidy, Pioneering in Big Business, 12.

9 Hidy and Hidy, Pioneering in Big Business, 417; Yergin, The Prize, 79. Alfred D. Chandler Jr., The Visible Hand: The Managerial Revolution in American Business (Cambridge: Harvard University Press, 1977), 321ff., 350-3, 418ff.

10 Keith Chapman, The International Petrochemical Industry: Evolution and Location (Oxford: Blackwell, 1991), esp. ch. 2-3; Jeffrey Meikle, American Plastic: A Cultural History (New Brunswick: Rutgers University Press, 1995), ch. 1-5.

11 Barrie Scardino Bradley, Improbable Metropolis: Houston's Architectural and Urban History (Austin: University of Texas Press, 2020), 89-90; Harvey J. Graff, The Dallas Myth: The Making and Unmaking of an American City (Minneapolis: University of Minnesota Press, 2008), 36-40; "Petroleum Art: Mobil's High-Flying Trademark," https://aoghs.org/petroleum-art/highflying-trademark/, accessed August 23, 2020.

12 Roger M. Olien and Diana Davis Olien, Oil Booms: Social Change in Five Texas Towns (Lincoln: University of Nebraska Press, 1982), ch. 2; David G. McComb, The City in Texas: A History (Austin: University of Texas Press, 2015), ch. 21.

13 These two paragraphs draw on Yergin, The Prize, 70-79, 215-17; Diana Davids Olien and Roger M. Olien, Oil in Texas: The Gusher Age, 1895-1945 (Austin: University of Texas Press, 2002), 29-74; Keith L. Bryant and Henry C. Dethloff, A History of American Business, 2nd ed. (Englewood Cliffs, NJ: Prentice-Hall, 1990), 164-65.

14 Robert Fairbanks, For the City as a Whole: Planning, Politics, and the Public Interest in Dallas, 19001965 (Columbus: Ohio State University Press, 1998); Amy Bridges, Morning Glories: Municipal 
Reform in the Southwest (Princeton, NJ: Princeton University Press, 1998). On the so-called "oil curse" and the divergent experiences of urban regions with it, Joseph Pratt et al., conclusion to Pratt, Melosi, and Brosnan, Energy Capitals, 181-96.

15 Olien and Olien, Oil in Texas, 59; Clay McShane, Down the Asphalt Path: The Automobile and the American City (New York: Columbia University Press, 1994), ch. 5-6.

16 Yergin, The Prize, 76. Jones, Routes of Power, ch. 4, Hidy and Hidy, Pioneering in Big Business, 172ff. Mark H. Rose, Cities of Heat and Light: Domesticating Gas and Electricity in Urban America (University Park: Penn State University Press, 1995), ch. 1-2; Christopher James Castaneda, Regulated Enterprise: Natural Gas Pipelines and Northeastern Markets (Columbus: Ohio University Press, 1993); William R. Childs, The Texas Railroad Commission: Understanding Regulation in America to the Mid-Twentieth Century (College Station: Texas A\&M University Press, 2005), esp. ch. 5.

17 These two paragraphs: Joseph A. Pratt, "A Mixed Blessing: Energy, Economic Growth, and Houston's Environment," and William C. Barnett, "A Tale of Two Cities: Houston, the Industrial Metropolis, and Galveston, the Island Getaway," in Energy Metropolis: An Environmental History of Houston and the Gulf Coast, eds. Martin V. Melosi and Joseph A. Pratt (Pittsburgh, PA: University of Pittsburgh Press, 2007), 21-33, 185-204; Martin V. Melosi and Joseph A. Pratt, "The Energy Capital of the World? Oil-Led Development in Twentieth-Century Houston," in Pratt, Melosi, and Brosnan, Energy Capitals, 30-57; Joseph J. Pratt and Christopher J. Castaneda, Builders: Herman and George R. Brown (College Station: Texas A\&M University Press, 1999); Joseph A. Pratt, The Growth of a Refining Region (Greenwich, CT: JAI Press, 1980).

18 Bradley, Improbable Metropolis, 151-52; Christopher Sellers, "Petropolis and Environmental Protest in Cross-National Perspective: Beaumont-Port Arthur, Texas, versus Minatitlan-Coatzacoalcos, Veracruz," Journal of American History 99 (June 2012): 111-23.

19 Rodney Crowell, Chinaberry Sidewalks: A Memoir (New York: Random House), 2011, $10-12$.

20 Tylna Steptoe, Houston Bound: Culture and Color in a Jim Crow City (Berkeley: University of California Press, 2016), esp. ch. 2; Emilio Zamora, Claiming Rights and Righting Wrongs: Mexican Workers and Job Politics during World War II (College Station: Texas A\&M University Press, 2009); Alan Lessoff, Where Texas Meets the Sea: Corpus Christi and Its History (Austin: University of Texas Press, 2015), esp. 45-48, 131-39.

21 Lessoff, Where Texas Meets the Sea, 41-45, 65-69, 267-71. Mary Jo O'Rear, Storm over the Bay: The People of Corpus Christi and Their Port (College Station: Texas A\&M University Press, 2009).

22 Sarah Elkind, "Los Angeles: The Energy Capital of Southern California," in Pratt, Melosi, and Brosnan, Energy Capitals, 77-89; Jason Cooke, "Energy Landscape: Los Angeles Harbor and the Establishment of Oil-Based Capitalism in Southern California, 1871-1930," Planning Perspectives 32 (January 2017): 67-86; Fred W. Viehe, "Black Gold Surburbs: The Influence of Extractive Industry on the Suburbanization of Los Angeles, 1890-1930," Journal of Urban History 8 (November 1981): 3-26.

23 Myrna Santiago, "Tampico, Mexico: The Rise and Decline of an Energy Metropolis," in Pratt, Melosi, and Brosnan, Energy Capitals, 147-58; Yergin, The Prize, 194-220, 254-60.

24 D. W. Meinig, Imperial Texas: An Interpretive Essay in Cultural Geography (Austin: University of Texas Press, 1969), 80; Matthew N. Eisler, "At Arm's Length: Energy and the Construction of a Peripheral Prairie Petrometropolis," in Pratt, Melosi, and Brosnan, Energy Capitals, 114. Carl Abbott, The Metropolitan Frontier: Cities in the American West (Tucson: University of Arizona Press, 1993), 159-61; Abbott, How Cities Won the West, 248-50.

25 Hidy and Hidy, Pioneering in Big Business, 401-02, 420. Craig E. Colten, "An Incomplete Solution: Oil and Water in Louisiana," Journal of American History 99 (June 2012): 91-99; Craig E. Colton, "Making a Lemon out of Lemonade: Louisiana's Petrochemical Corridor," in Pratt, Melosi, and Brosnan, Energy Capitals, 58-76.

26 Colten, “An Incomplete Solution," 91, 94; also Colten, An Unnatural Metropolis: Wrestling New Orleans from Nature (repr. Baton Rouge: Louisiana State University Press, 2005), 125-31.

27 Barbara L. Allen, Uneasy Alchemy: Citizens and Experts in Louisiana's Chemical Corridor Disputes (Cambridge: MIT Press, 2003), 1-2; Ashley Dawson, Extreme Cities: The Peril and Promise of Urban Life in the Age of Climate Change (New York: Verso, 2017), 115; Tyler Priest, "Shrimp and Petroleum: The Social Ecology of Louisiana's Offshore Industries," Environmental History 21 (July 2016): 488-515.

28 David Foster Wallace, “This Is Water," repr. at https://fs.blog/2012/04/david-foster-wallacethis-is-water/, accessed July 20, 2020. 